Article

\title{
Porosity, Surface Quality, Microhardness and Microstructure of Selective Laser Melted 316L Stainless Steel Resulting from Finish Machining
}

\author{
Yusuf Kaynak * and Ozhan Kitay \\ Department of Mechanical Engineering, Marmara University, 34722 Istanbul, Turkey; ozhankitay@hotmail.com \\ * Correspondence: yusuf.kaynak@marmara.edu.tr or yusuf_kaynak@yahoo.com; Tel.: +90-216-336-5770
}

Received: 30 April 2018; Accepted: 1 June 2018; Published: 5 June 2018

check for updates

\begin{abstract}
Among additive manufacturing (AM) techniques, Selective Laser Melting (SLM) is widely used to fabricate metal components, including biocompatible bone implants made of 316L stainless steel. However, an issue with the components manufactured using this technique is the surface quality, which is generally beyond the acceptable range. Thus, hybrid manufacturing, including AM and finish machining processes, are being developed and implemented in the industry. Machining processes, particularly finish machining, are needed to improve surface quality of additively manufactured components and performance. This study focuses on the finish machining process of additively manufactured 316L stainless steel parts. Finish machining tests were carried out under dry conditions for various cutting speeds and feed rates. The experimental study reveals that finish machining resulted in up to $88 \%$ lower surface roughness of SLMed 316L stainless steel; it also had a substantial effect on microstructure and microhardness of the additively manufactured components by creating smaller grains and strain-hardened layer on the surface and subsurface of the SLMed part. The finish machining process also significantly decreased the density of porosity on the surface and subsurface, compared to an as-built sample. The created strain harden layer with less porosity is expected to increases wear and fatigue resistance of these parts.
\end{abstract}

Keywords: selective laser melting; surface integrity; porosity; 316L stainless steel; finish machining

\section{Introduction}

Additive manufacturing enables the production of complex-shaped parts and rapid prototypes that cannot be produced by machining methods $[1,2]$. Because of these advantages, it is a preferred method in the biomedical, aerospace, and automotive fields [3]. In addition to various AM methods [4,5], a preferred one is the selective laser melting method [6-8]. SLM technology enables the use of different materials in manufacturing and assembly of different powder materials to produce parts that meet specific needs [9].

Although the SLM process provides many advantages as compared to conventional machining, its one of the major drawbacks is the low surface quality resulting from this process $[10,11]$. Surface quality is greatly influenced by the "stair step" effect, which is the stepped approximation by layers of curves and inclined surfaces [12]. This effect is present, to a greater or lesser degree, in all additive layer manufacturing processes and a consequence of the additive deposition and fabrication of layers [12]. Despite the fact that layer thickness can be reduced to improve surface quality, obtaining an acceptable surface quality is a very important issue in SLM production as poor surface quality could lead to long and expensive post-finishing operations [12]. The surface quality of metallic SLMed parts is influenced by many factors; such as-built orientation [13] laser parameters-laser power, scanning speed, hatching distance, etc. [14]—and powder size [15]. In addition to surface quality, subsurface 
characteristics of additively manufactured components are also important and need to be taken into account. As a source of problems encountered in the additive manufacturing processes, internal stresses due to temperature difference during the process and shrinkage in work piece size after melting are shown [16]. It should also be noted that laser parameters substantially affect surface microstructure [17]. When studies are examined that focuses on the 316L stainless steel produced by the SLM additive manufacturing method, it is generally observed that the main concern is the only on changes in the properties after additive manufacturing. Thus, microstructure [6,18-20], fracture behavior [19,20], mechanical properties [18] fatigue performance [7,21], and residual stress [20,22], were investigated and reported in the literature. However, surface characteristics or enhancing approaches of surface characteristics have not extensively investigated as yet; although, the functionality of AM parts is highly dependent on the geometric and dimensional accuracy, as well as the surface integrity [23]. As hybrid method includes both SLM and finish machining, and finish machining is being used to improve the surface property, it is inecessary to investigate the effects of the finishing process on the surface and subsurface characteristics of additively manufactured parts. When reviewing the literature, it seems that extensive studies on the machining-induced surface integrity characteristics of 316L stainless steel produced by AM are not yet available [4]. Surface characteristics, including roughness and topography induced from processing, is vital [24-26]. Thus, their effects on the surface of SLMed components should be carefully examined. Few studies have reported that post-finishing processes such as laser re-melting [10], electrochemical and abrasive flow machining [27] and milling processes [28] have improved surface characteristics of SLMed parts.

316L stainless steel has been widely used in biomedical industries to manufacture custom-made biocompatible metal bone implants [29]. Together with AM, it is well-suited for these applications, as implants or prostheses can be individualized with very low customization costs [29]. As these implants have interactions with the human body, their surface and subsurface characteristics should be given special attention. Enhancing the surface and subsurface characteristics with post-processing will substantially help to widen the use of AM in the industry. As a post-processing operation, finish machining processes, including turning and milling, can be utilized to improve surface characteristics and control subsurface properties. Depending on the geometry of SLMed parts, either turning operation or milling operation can be used. In some cases, both needs to be used simultaneously. However, it should be noted that as a post-finishing operation the thermomechanical effect of both turning and milling on the surface and subsurface of SLMed parts is expected to be similar.

In this study, the influence of the finish turning process on surface and subsurface characteristics of additively manufactured 316 stainless steel is investigated and presented. As a hybrid process is considered, no coolant or lubrication was applied during the finishing process. The effect of cutting speed and feed rate on the surface and subsurface characteristics of additively manufactured parts are also examined. Surface hardening tendency, reduced porosity on the surface and subsurface, and subsurface alteration by smaller grain sizes are observed. Surface roughness is vitally reduced by the finishing operation.

\section{Materials and Methods}

\subsection{Work Material}

The workpiece used in this study was selective laser melted (SLMed) 316L stainless steel as round bars of $15 \mathrm{~mm}$ diameter and $80 \mathrm{~mm}$ length. These parts were produced using Selective Laser Melting by Renishaw AM250 under Ar atmosphere. Meander hatch pattern strategy was used to build parts used in this study. SLM laser process parameters are presented in Table 1. The as-built hardness of SLMed 316L is $260 \pm 7 \mathrm{HV}$. All specimens used in this study were in as-built condition. Built direction is shown in Figure 1. 
Table 1. Selective Laser Melting process parameters.

\begin{tabular}{cccc}
\hline Particle Size of Powder & $14-45 \mu \mathrm{m}$ & Point Distance & $60 \mu \mathrm{m}$ \\
Layer Thickness & $50 \mu \mathrm{m}$ & Exposure Time & $80 \mu \mathrm{s}$ \\
Power & $200 \mathrm{~W}$ & Hatch Distance & $110 \mu \mathrm{m}$ \\
\hline
\end{tabular}

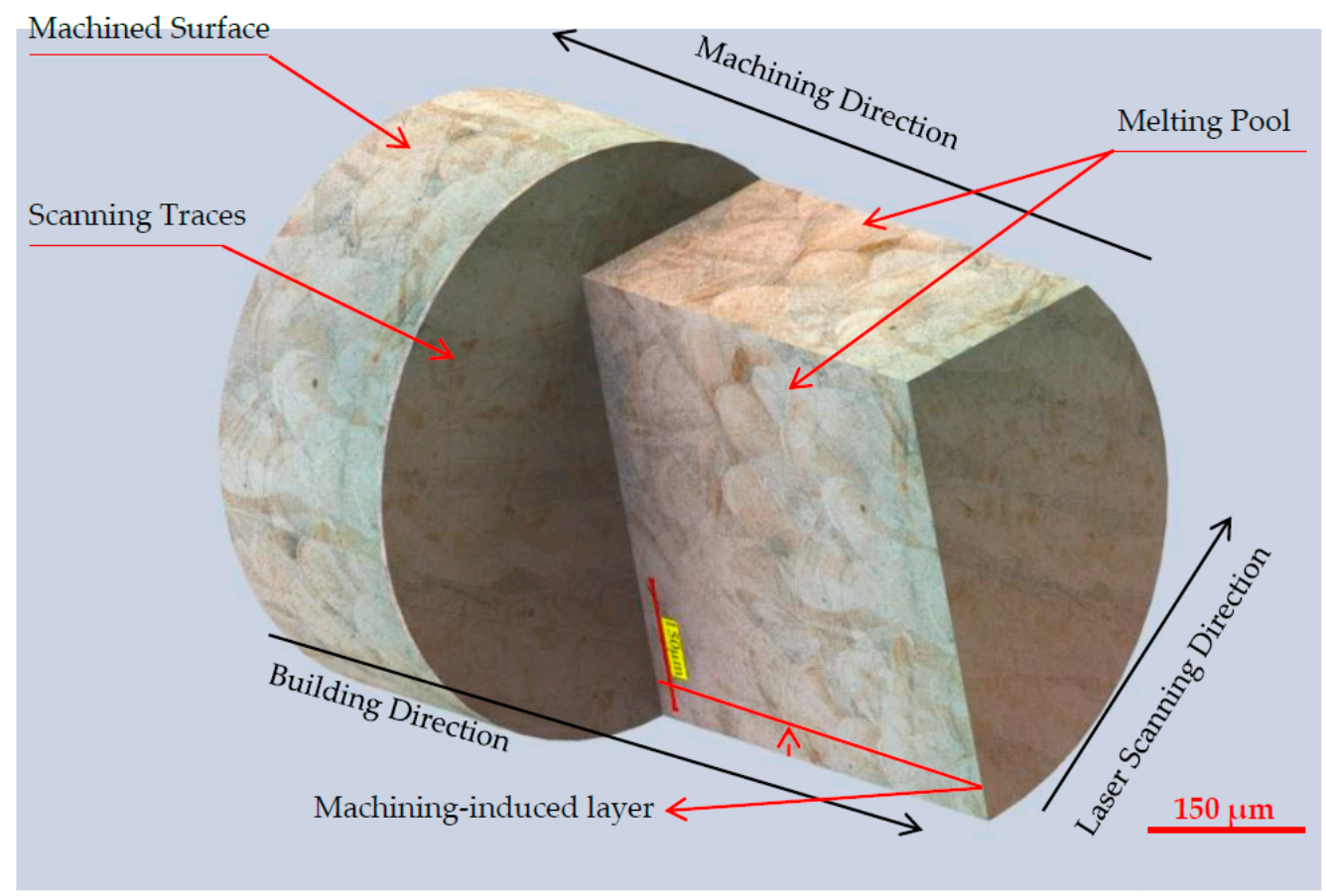

Figure 1. Microstructure and building directions of as-built SLMed 316L sample.

\subsection{Finish Machining Operation}

The finish machining experiments were conducted on a CNC turning center, which has maximum spindle speed of $4500 \mathrm{rpm}$ and $18 \mathrm{~kW}$ power. CNMG 120404 Grade A155 with $-6^{\circ}$ rake angle cutting tool was used in all machining experiments. Cutting speeds were selected as 50, 100, 150 and $200 \mathrm{~m} / \mathrm{min}$. In machining tests, depth of cut $\left(a_{p}\right)$ was kept constant at $0.4 \mathrm{~mm}$ and feed rates $(f)$ of 0.08 , 0.16 , and $0.24 \mathrm{~mm} / \mathrm{rev}$, were used. Finish machining operations were performed under dry machining conditions without any coolant and lubricant, as depicted in Figure 2.

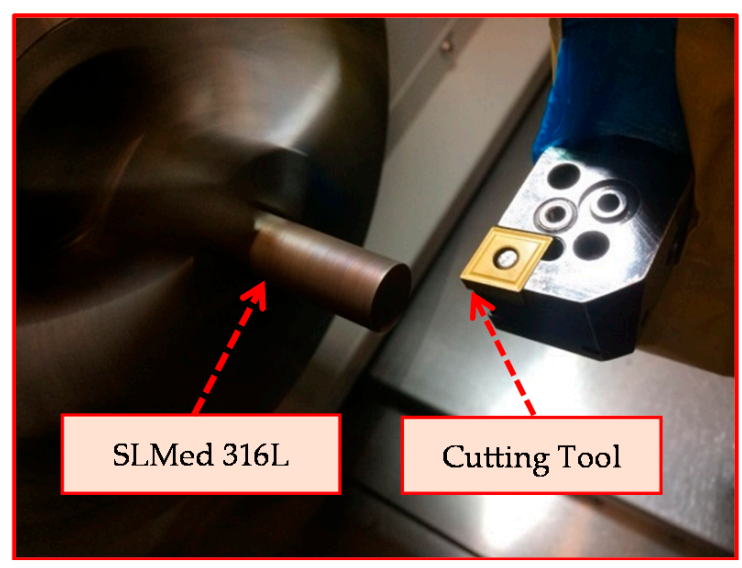

Figure 2. Experimental photography. 


\subsection{Measurements}

To examine surface characteristics (microhardness, microstructure, etc.), machined workpieces were cut with diamond-cutting disks, following which the specimens were cold-mounted in acrylic and polished using 60, 30 and $15 \mu \mathrm{m}$ grit magnetic discs. Specimens were etched using a solution of $2 \mathrm{~mL} \mathrm{HNO}_{3}+4 \mathrm{~mL}$ Glycerine $+6 \mathrm{~mL} \mathrm{HCl}$ to review the microstructure. Surface roughness values were measured by an average of four measurements using surface roughness tester (Mitutoyo SJ210, Kawasaki, Japan). All reported surface roughness values presented in this study are arithmetic average surface roughness, $R a$. Surface topography and microstructure of etched specimens were examined by Digital Optic Microscopy (Keyence, Osaka, Japan) and scanning electron microscope (SEM) (FEI Sirion XL-30, Portland State University Department of Physics, Portland, OR, USA). The microstructure of the selective laser melted 316L stainless steel is presented in Figure 3. Observed main microstructures are melting pool, melting pool boundary, large grains and sub-grains in the melting pools [30,31]. Both cellular and elongated grains are observed in the microstructure of as-built SLMed part. As was reported in literature by Prashant and Eckert [32], cellular microstructure is observed with cell sizes within $\mathrm{nm}$ to $\mu \mathrm{m}$ range. Sub-grains can be observed in a homogenous or heterogeneous structure in the melting pool, sometimes in extended form and different directions. The thermally melted granules by laser give the appearance of slipped grains in the melting pool, as clearly shown.

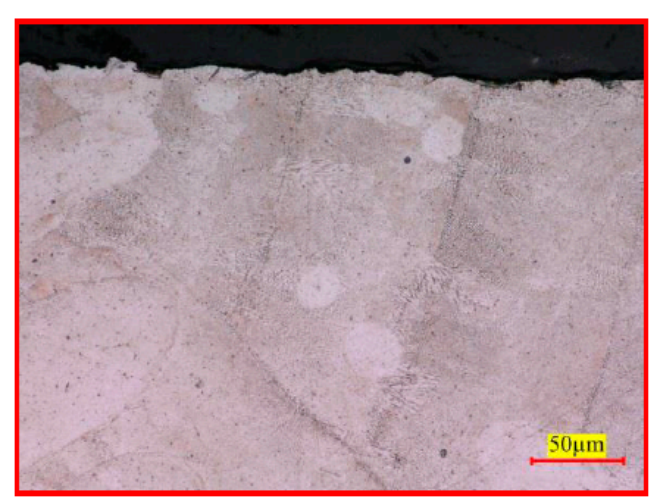

(a)

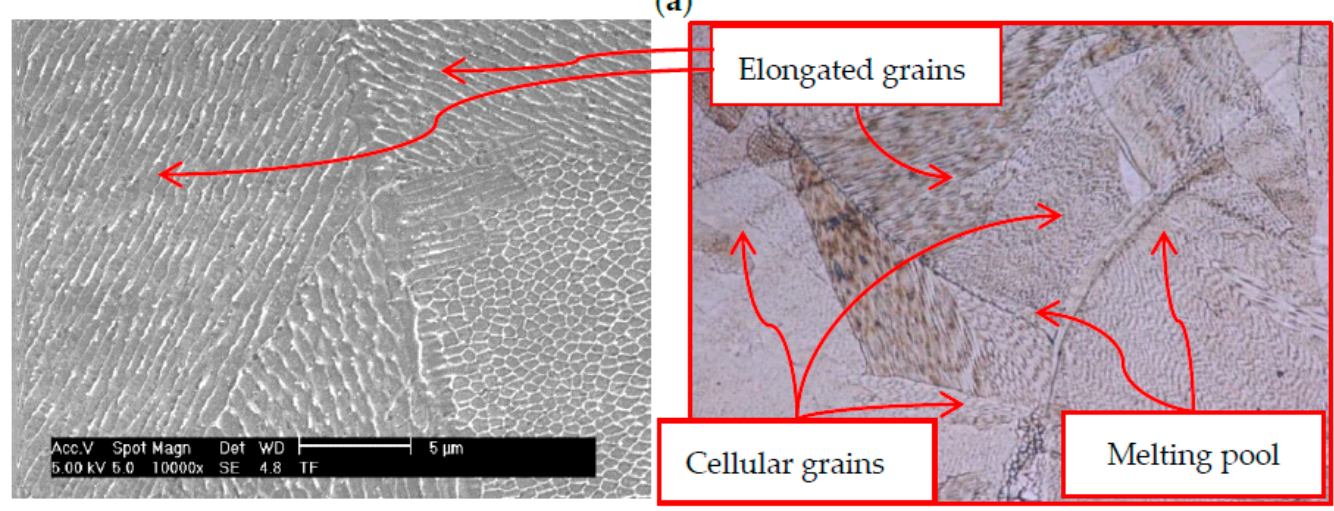

(b)

Figure 3. (a)Microstructure of surface and subsurface of as-built SLMed part, (b) The detail of melting pool and grain structure of as-built SLMed part.

Porosity level of as-built SLM samples were also measured with Keyence digital optical microscopy, using its image analysis tool. Figure 4 shows the porosities from the building direction of an as-built SLMed sample. 


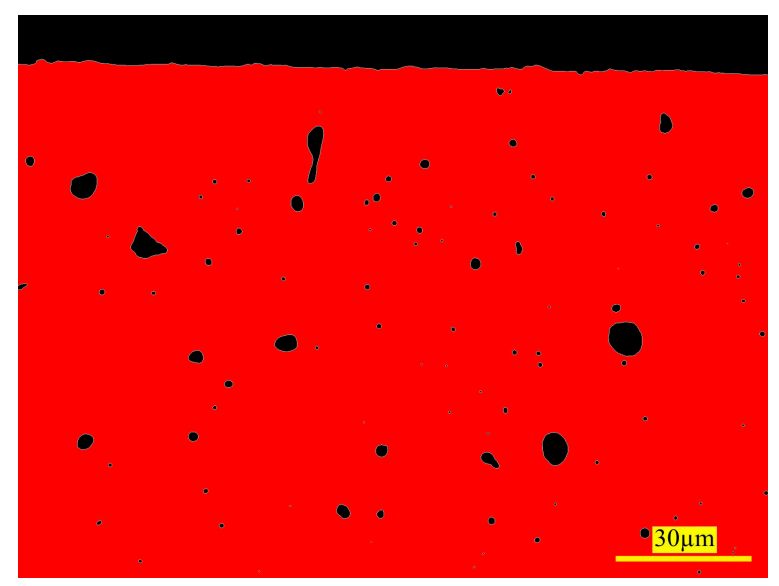

Figure 4. Optical images of porosities.

Microhardness of the workpiece was measured using Future-Tech FM310e. Hardness of the specimen was determined by an average of four measurements with a testing load of $50 \mathrm{gf}$ and a load dwelling time for $15 \mathrm{~s}$ was used.

\section{Results and Discussion}

\subsection{Porosity, Surface Quality and Topography}

Figure 5 shows the density of porosity observed in layers close to the surface and subsurface of as-built and machined SLMed samples. It is apparent that the density of porosity is much more in the as-built sample, when compared to machined ones. While the porosity is approximately $1.39 \%$ in an as-built sample, it is $0.25 \%$ at low-cutting speed and $0.48 \%$ at a higher-cutting speed. Overall finish machining resulted in reduction of porosity density on the surface and subsurface of SLMed parts. Two types of porosities were observed in the microstructure of the samples: one is spherical that occurs due to gas bubbles [33], and the other is a bigger and elongated porosity that occurs between the two melting pools [33] as shown with a red arrow in Figure 5. Elongated porosities are the result of partially melted powder particles and can be attributed to not enough melting of the new layer and not enough melting of the prior solidified material again [33]. The finish machining process eliminated partially melted powders on the surface and subsurface of samples, and notably reduced porosity density in these layers. This is mainly because of the elevated temperature and stress work material is subjected to during cutting process. Reduced porosity resulting from the finish machining process is expected to increase fatigue resistance.

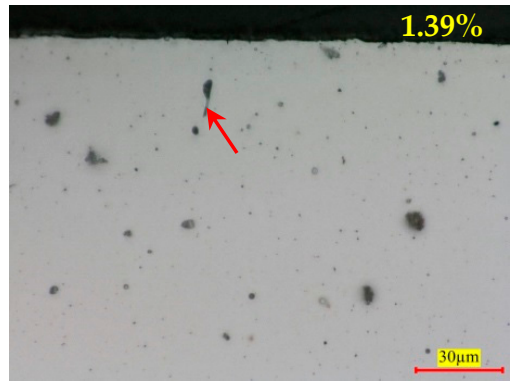

(a)

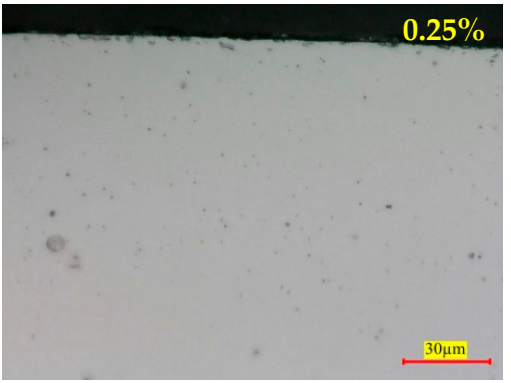

(b)

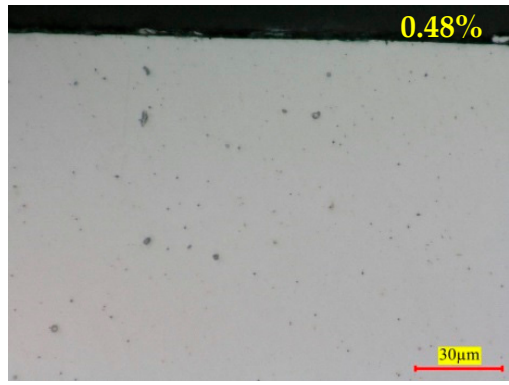

(c)

Figure 5. (a) Porosity observed on the surface and subsurface of as-built sample (b) Machined sample $\left(V_{c}=50 \mathrm{~m} / \mathrm{min}\right)$; (c) Machined sample $\left(V_{c}=200 \mathrm{~m} / \mathrm{min}\right)$. 
Although selective laser melting is an emerging approach due to its many advantages when compared to traditional manufacturing processes, one of the limitations is to produces a surface quality that is not within an acceptable range [34]. Fabricated components are expected to have a smooth surface with lower surface roughness in the conventional manufacturing process [35,36], and AM should be able to offer the same quality in order to become an alternative approach in the manufacturing industry. Average surface roughness ( $\mathrm{Ra}$ ) of SLMed as-built 316L stainless steel is approximately $7 \pm 1 \mu \mathrm{m}$, as shown in Figure 6. These measured values can be considered as very high, when compared to the surface quality of conventionally produced 316L stainless steel-generally less than $2 \mu \mathrm{m}$. Therefore, surface finishing is required to improve the surface quality of SLMed parts.
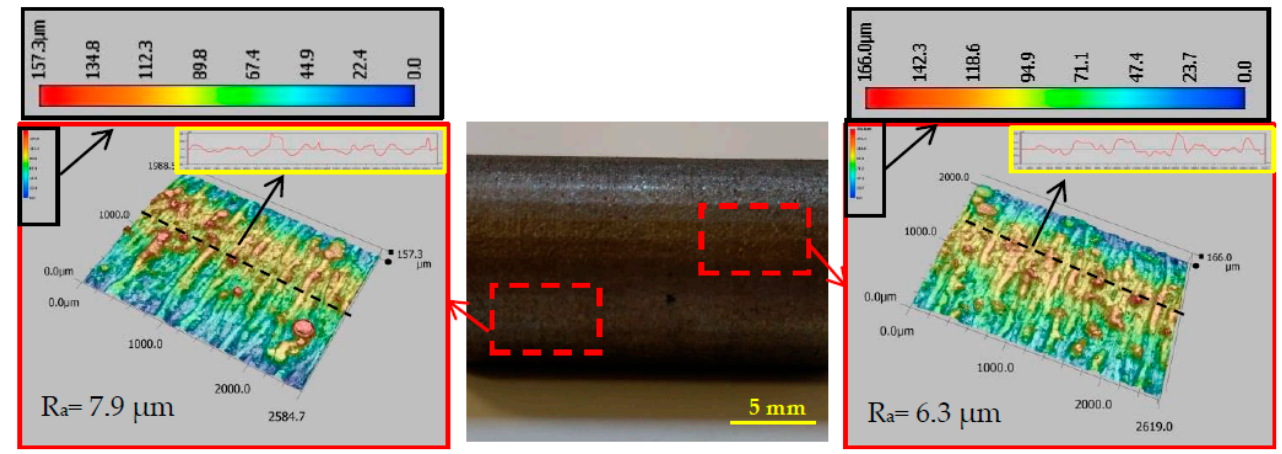

Figure 6. Surface topography of an as-built SLMed part.

To improve surface quality of as-built SLMed parts, finish machining operations were carried out. Surface topography of finish machined samples of additively manufactured 316L stainless steel at different feed rates are shown in Figure 7. Feed marks on the machined samples are visible at all feed rate values. When examining the changes of surface topographies as a function of feed rate, noticeable differences with the increasing feed rate is observed. The most favorable and the smoothest surface was obtained with the lower feed rate.

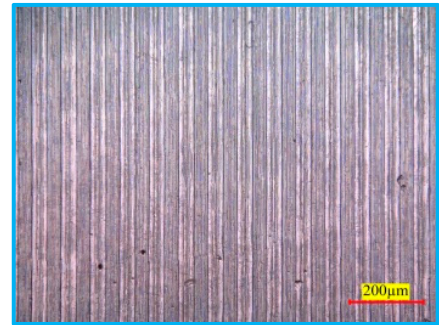

(a)

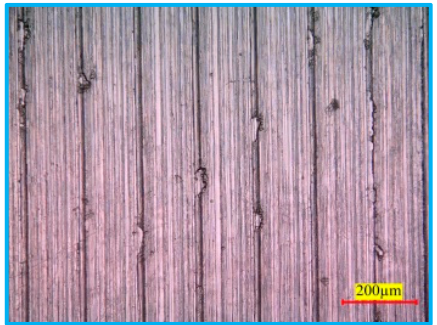

(b)

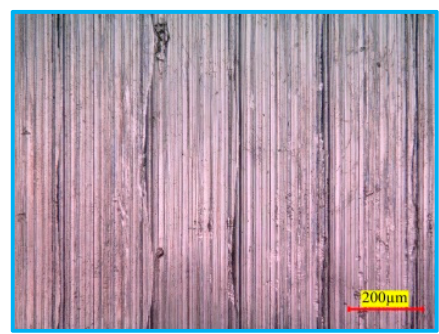

(c)

Figure 7. Surface topography of finish-machined SLMed $316 \mathrm{~L}$ stainless steel $\left(V_{c}=150 \mathrm{~m} / \mathrm{min}\right)$. (a) $f=0.08 \mathrm{~mm} / \mathrm{rev} ;(\mathbf{b}) f=0.16 \mathrm{~mm} / \mathrm{rev} ;(\mathbf{c}) f=0.24 \mathrm{~mm} / \mathrm{rev}$.

Surface topography of machined samples at different cutting speeds is shown in Figure 8. At low-cutting speeds, especially $100 \mathrm{~m} / \mathrm{min}$, debris reattachment to the machined surface is observed, leading to increased surface roughness. However, at high-cutting speeds $(200 \mathrm{~mm} / \mathrm{min})$, feed marks are very narrow, resulting in a much smoother surface.

Average surface roughness of machined samples as a function of feed rate is illustrated in Figure 9. It is a well-known fact that increasing feed rate results in increased surface roughness. There is an increasing trend on surface roughness when feed rate is increased, as depicted in Figure 9. Measured average roughness values ( $\mathrm{Ra}$ ) are $0.8,2.14$ and $2.54 \mu \mathrm{m}$ at $0.08,0.16$, and $0.24 \mathrm{~mm} / \mathrm{rev}$ feed rates, respectively. There is a $217 \%$ increase in surface roughness from the lowest feed rate of 
$0.08 \mathrm{~mm} / \mathrm{rev}$ to the highest feed rate of $0.24 \mathrm{~mm} / \mathrm{rev}$. Topography images for these cutting conditions (presented in Figure 7) support these obtained values.

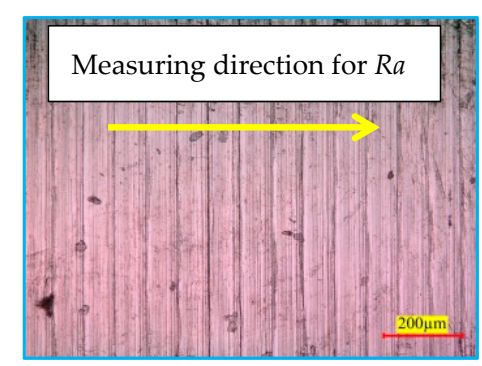

(a)

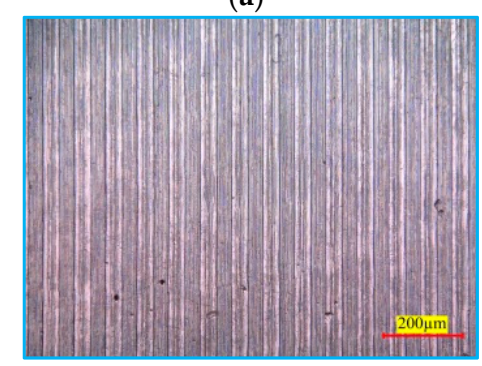

(c)

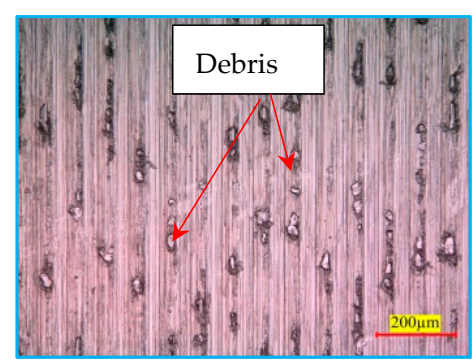

(b)

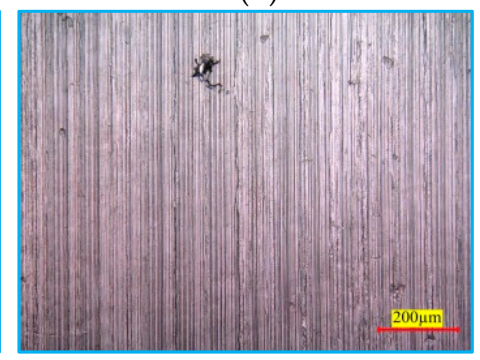

(d)

Figure 8. Surface topography of finish-machined SLMed 316L stainless steel $(f=0.08 \mathrm{~mm} / \mathrm{rev})$. (a) $V_{c}=50 \mathrm{~m} / \mathrm{min}$; (b) $V_{c}=100 \mathrm{~m} / \mathrm{min} ;(\mathbf{c}) V_{c}=150 \mathrm{~m} / \mathrm{min}$; (d) $V_{c}=200 \mathrm{~m} / \mathrm{min}$.

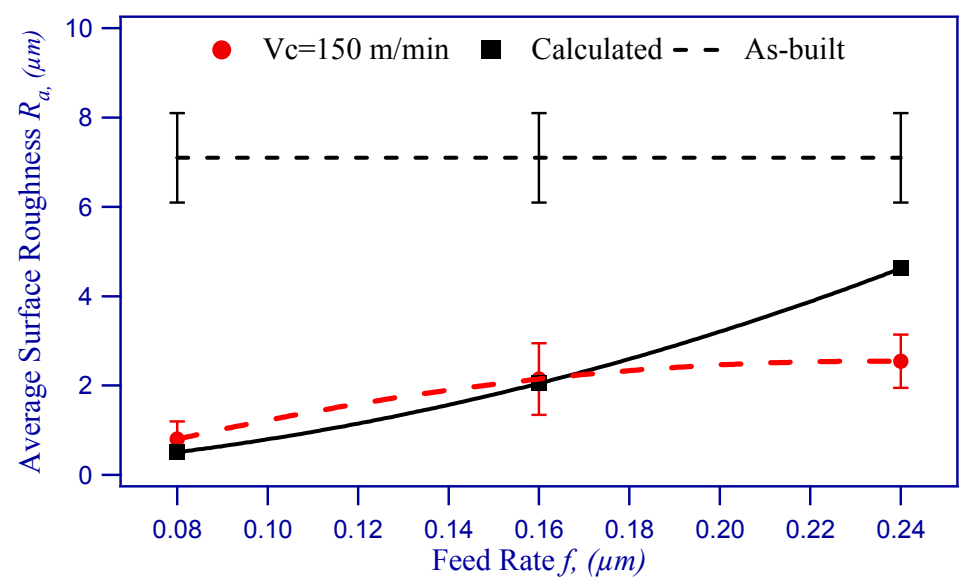

Figure 9. Surface roughness of finish-machined SLMed 316L stainless steel as a function of the feed rate.

On the other hand, using the following equation [37], the surface roughness values for various feed rates are also calculated.

$$
R_{a}=\frac{0.0321 \times f^{2}}{r_{c}}
$$

where, $f$ indicates feed rate, and $r_{c}$ indicates nose radius of the cutting tool used in this finishing operation. At 0.08 and $0.16 \mathrm{~mm} / \mathrm{rev}$, predicted values of surface roughness shows good agreement with experimentally measured values, as shown in Figure 9; however at $0.24 \mathrm{~mm} / \mathrm{rev}$ feed rate, large variation in between predicted and experimentally measured is recorded. This is mainly due to the increased nose radius of the cutting insert, resulting from wear occurs during cutting process.

Average surface roughness values at different cutting speeds are illustrated in Figure 10. Roughness values do not show a uniform trend as a function of the cutting speed. Roughness 
increased from a cutting speed of $50 \mathrm{~m} / \mathrm{min}$ to $150 \mathrm{~m} / \mathrm{min}$, followed by a decreasing trend at a cutting speed of $200 \mathrm{~m} / \mathrm{min}$. Average surface roughness values measured are $0.44,0.81,0.8$ and $0.57 \mu \mathrm{m}$ at cutting speeds of 50,100, 150 and $200 \mathrm{~m} / \mathrm{min}$, respectively. Sharp reduction in surface roughness value at the highest cutting speed can be attributed to tool wear at nose region of tool, resulting from an increased cutting temperature at high-cutting speed. Increased nose radius of cutting tool is expected to generate much smoother surface considering the Equation (1), presented above. It should be also noted that the difference is $84 \%$ in between the lowest and highest roughness values within these selected cutting speeds.

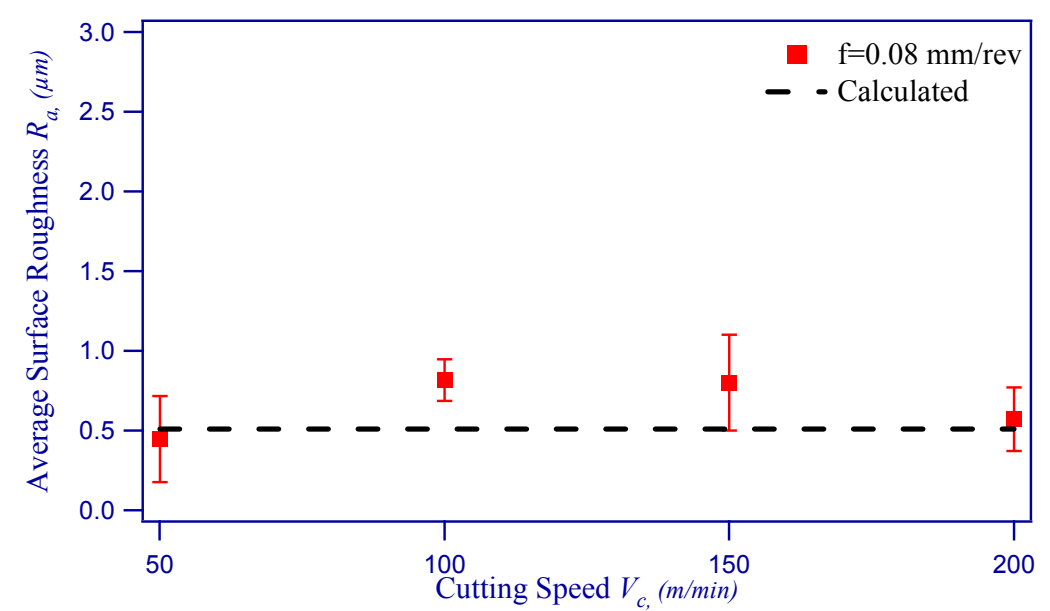

Figure 10. Surface roughness of finish-machined SLMed 316L stainless steel as a function of cutting speed.

Overall results demonstrate that the finish machining process makes a substantial contribution to enhance the surface quality of selective laser melted 316L stainless steel by notably reducing surface roughness of as-built components. However, it should be also noted that cutting parameters including feed rate and cutting speed at the finishing operation play a dominant role in controlling the surface quality of SLMed parts.

\subsection{Microstructure}

Mechanical properties of metal parts vary significantly with microstructure, including the phase type, grain size and shape, dendrite, and element segregation [38]. Optical microscopy images of the microstructure of SLMed parts subjected to finish machining at different feed rates are shown in Figure 11. The effect of finish machining on the microstructure is more visible in the region that is close to the surface, where smaller size cells are observed. The results of the plastic deformation that occurs in the surface zone of the material is depicted in Figure 11. While cell size is smaller than $1 \mu \mathrm{m}$ close to the surface area that is deeply induced from machining, cell size is generally above $1 \mu \mathrm{m}$ within much deeper layers that are not affected by the machining process.

The effects of cutting speed on the microstructure of SLMed parts are shown in Figure 12. The size of cellular grain is generally less than $1 \mu \mathrm{m}$. Just below the machined surface, even slipped grain within the same pool showed refinement; however, more slipping is also observed in much deeper layers, which might be a result of both temperature and stress generated by the finish-cutting process. These slipped grains are found more at the cutting speeds of $150 \mathrm{~m} / \mathrm{min}$ and $200 \mathrm{~m} / \mathrm{min}$, than at cutting speeds of $50 \mathrm{~m} / \mathrm{min}$ and $100 \mathrm{~m} / \mathrm{min}$. Observation of the microstructure of SLMed parts after the finish machining process shows a clear machining-induced layer. However, the depth of this layer depends on cutting parameters and is generally less than $20 \mu \mathrm{m}$ under optical microscopy. Further examination by techniques such as TEM might make it possible to observe in detail the effect of machining on deeper layers of the samples. 

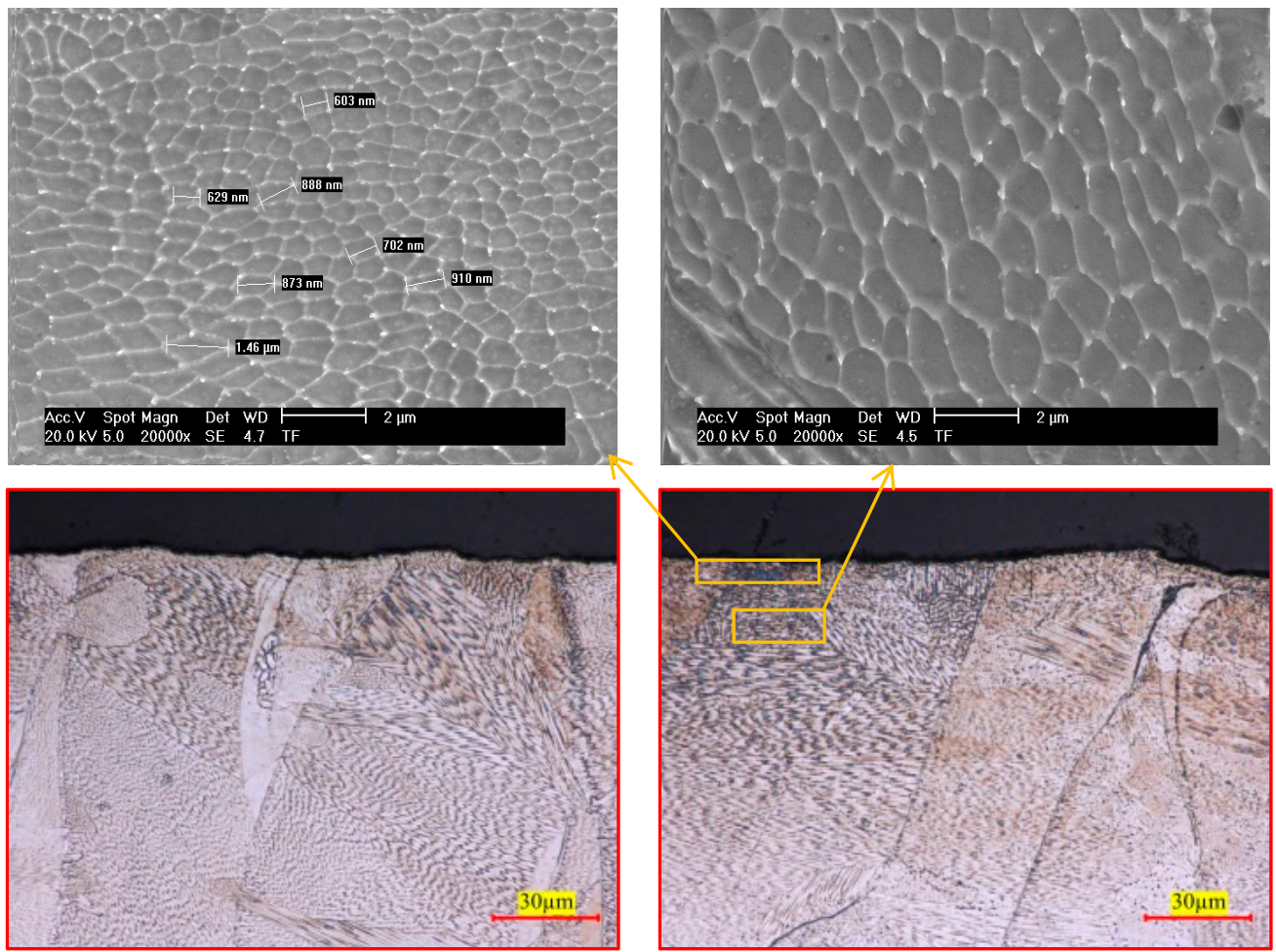

$f=0.08 \mathrm{~mm} / \mathrm{rev}$

$f=0.16 \mathrm{~mm} / \mathrm{rev}$

Figure 11. The effect of feed rate on microstructure of SLMed 316L part $\left(V_{c}=150 \mathrm{~mm} / \mathrm{min}\right)$.

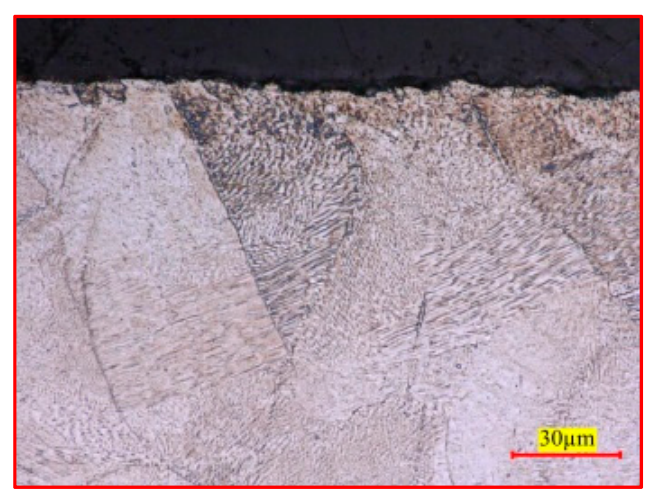

$V_{c}=50 \mathrm{~m} / \mathrm{min}$

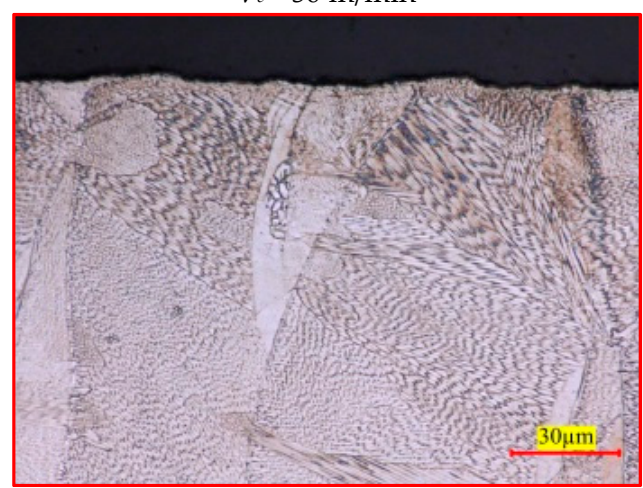

$V_{c}=150 \mathrm{~m} / \mathrm{min}$

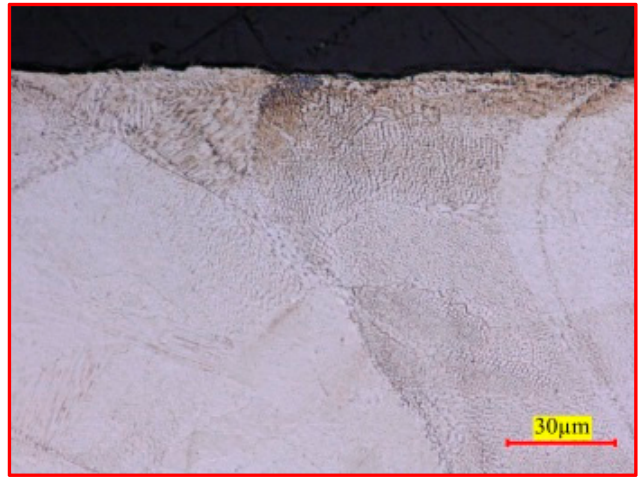

$V_{c}=100 \mathrm{~m} / \mathrm{min}$

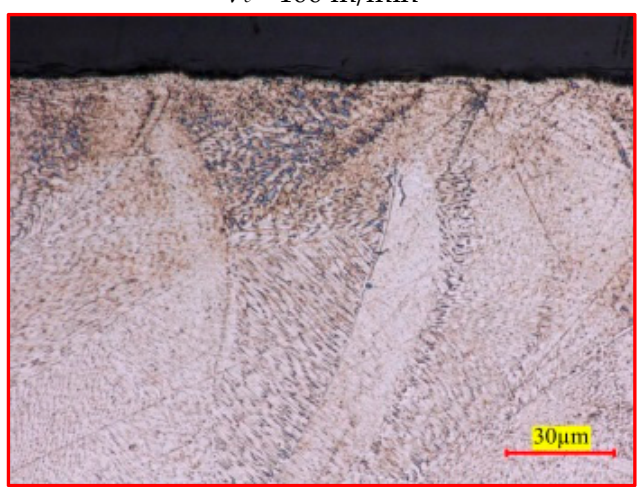

$V_{c}=200 \mathrm{~m} / \mathrm{min}$

Figure 12. The effect of cutting speed on microstructure of SLMed 316L part $(f=0.08 \mathrm{~mm} / \mathrm{rev})$. 


\subsection{Microhardness}

One of the significant surface characteristics of metallic material is surface hardness, which influences the response capability of components subjected to various environmental, frictional, and contact conditions. Although determination of surface and subsurface hardness is important after post-processing of wrought metallic material, this examination is more vital for additively manufactured components and selective laser melted components, as highly localized heat input results in large thermal gradients and, consequently, high thermal stresses occurs during the process [39]. As the machining process inherently generates stress and temperature on the surface of machined parts, this eventually influences the microhardness response of surface and subsurface of components [40].

Microhardness of finish-machined SLMed samples at different cutting speeds is illustrated in Figure 13. The hardness of finish-machined SLMed samples at all cutting speeds increased substantially as compared to as-built SLMed sample. The large difference in finish-machined samples and as-built SLMed parts is observed at approximately $50 \mu \mathrm{m}$ from the surface. As the cutting speed increases, it is observed that the average microhardness increases, which is generally not an expected response of 316L stainless steel. Increased speed leads to increased temperature, which generally leads to thermal softening and consequently reduced hardness in wrought material [40]. SLMed parts, however, show a completely difference response, as illustrated. While the highest average hardness value was measured as $306 \mathrm{HV}$ at a cutting speed of $200 \mathrm{~m} / \mathrm{min}$, the lowest average hardness value was measured as $282 \mathrm{HV}$ at a cutting speed of $50 \mathrm{~m} / \mathrm{min}$, at a distance of $15 \mu \mathrm{m}$ from the surface. When speed is increased from $50 \mathrm{~m} / \mathrm{min}$ to $200 \mathrm{~m} / \mathrm{min}$, an $8 \%$ increase in hardness is observed. Besides, hardening at the highest and lowest cutting speeds is $17 \%$ and $9 \%$, respectively, when the hardness of as-built material is taken into account. The machining process induces stress and consequently increases dislocation density on the surface and subsurface, which is the main reason for increased hardness on the surface and subsurface of machined SLMed parts. It is also a well-acknowledged fact that increased cutting speed leads to increased strain rates. Deformation with higher strain rate resulting from higher cutting speeds might also be the reason for larger strain hardening and consequently increased microhardness on the surface and subsurface of the SLMed part. Moreover, it was depicted that the grains on the surface and subsurface becomes smaller than the bulk of material as shown in the previous section. This is also expected to alter microhardness measured on the surface and subsurface, as increased microhardness might be the result of smaller grains, considering the well-known Hall-Petch model [41].

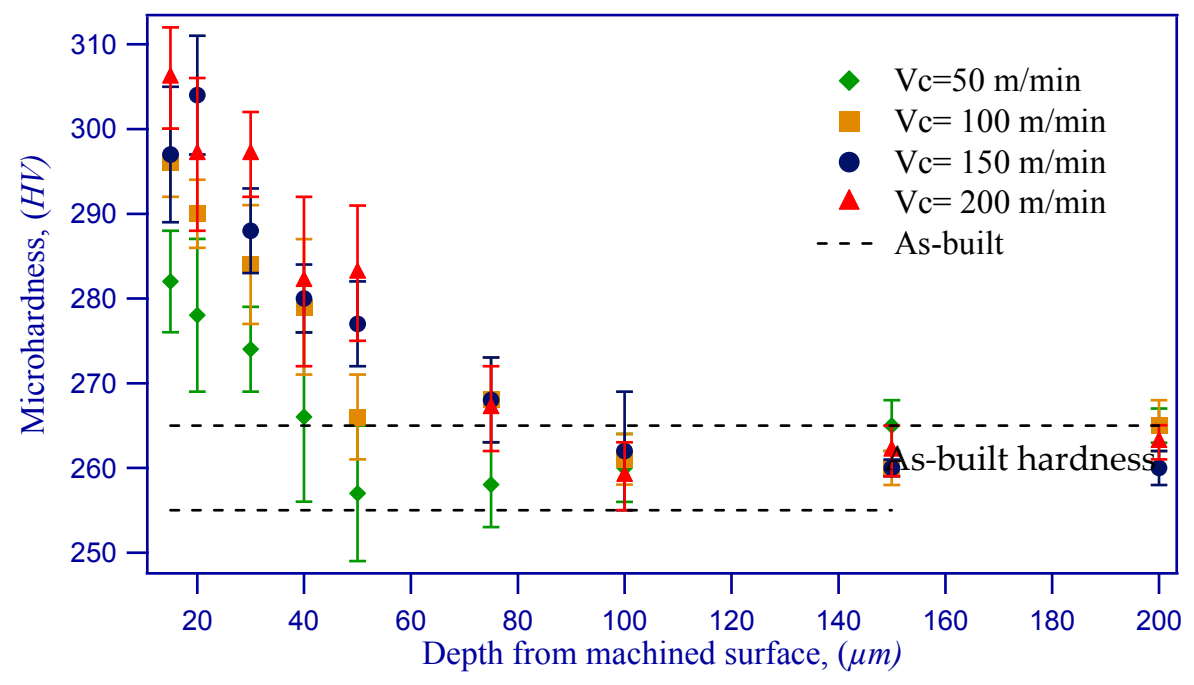

Figure 13. Microhardness of finish-machined and as-built SLMed 316L stainless steel as a function of cutting speed $(f=0.08 \mathrm{~mm} / \mathrm{rev})$. 
Hardness values of machined samples at different feed rates are shown in Figure 14. Similar to Figure 13, hardening occurs at all feed rate values; the measured hardness values also increase with increased feed rate. $320 \mathrm{HV}$ that is the highest average hardness values, measured at feed rates of $0.24 \mathrm{~mm} / \mathrm{rev}$. The difference in the highest and the lowest measured hardness values in machined sample is approximately $7 \%$. In addition, hardening at the highest and the lowest feed rates are 23 and $14 \%$, respectively, considering the hardness of as-built material. It should be noted that increased hardness leads to increased wear resistance of work material [42]. Thus, it is possible to conclude that post processing helps the SLMed part to increase wear resistance.

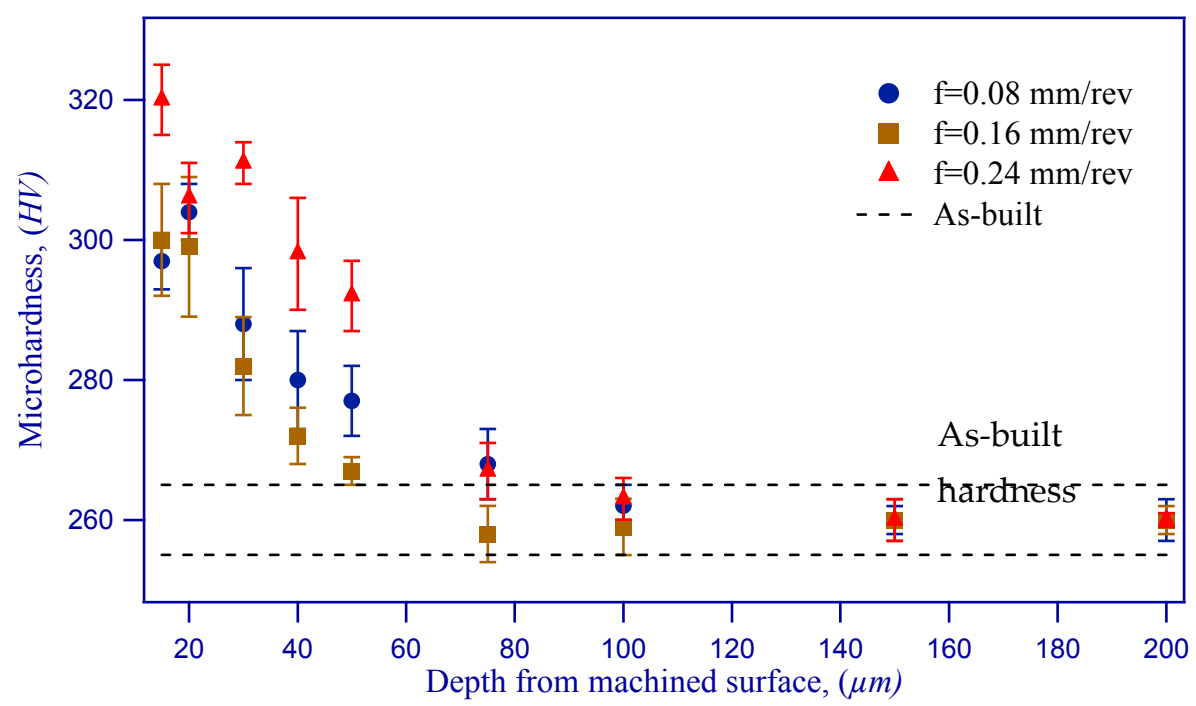

Figure 14. Microhardness of finish- machined and as-built SLMed 316L stainless steel as a function of feed rate $\left(V_{c}=150 \mathrm{~m} / \mathrm{min}\right)$.

\section{Conclusions}

Additive manufacturing is of interest to the biomedical industry; the main concern of additively manufactured parts, however, is surface characteristics. Finish machining to improve the surface of components as a part of hybrid manufacturing seems to be an easily implemented approach. This study provides experimental investigation into the effects of finish machining on the surface enhancement capability of SLMed 316L stainless steel. The following conclusions can be drawn from this study:

- The finish machining process substantially reduces porosity rate on the surface and subsurface of SLMed parts, as compared to as-built SLMed parts. This will eventually help to reduce the risk of fatigue failure that originates from the surface and/or subsurface of components due to porosity.

- The finish machining process vitally reduces the surface roughness of SLMed 316L stainless steel and thus enhances the surface quality of SLMed parts. While as-built parts have surface roughness $\left(R_{a}\right)$, that is approximately $7 \pm 1 \mu \mathrm{m}$, the finish machining process reduces this value below $1 \mu \mathrm{m}$, demonstrating a significant enhancement of surface quality.

- Microstructure and grain size close to the surface of SLMed 316L stainless steel is affected by the finish machining operation. The thickness of the machining-induced layer is found to be approximately $10-20 \mu \mathrm{m}$. In that particular layer, grains become much smaller as compared to much deeper layers from the surface of parts. In addition, slipped grains are much visible, induced by plastic deformation resulting from the cutting process.

- The finish machining process leads to strain hardening on the surface and subsurface of SLMed parts. Considering the microhardness of as-built material, approximately $9 \%$ to $23 \%$ increase in hardness (depending on cutting conditions) is observed. 
Author Contributions: Y.K. designed, supervised the experimental works, reviewing and editing the manuscript. O.K carried out the experimentations, plots the data and wrote the first draft of manuscript. Final version of manuscript was read and approved by the coauthors.

Acknowledgments: Authors acknowledge Renishaw Turkey for providing SLMed 316L stainless steel work materials for this study.

Conflicts of Interest: The authors declare no conflict of interest.

\section{References}

1. Kranz, J.; Herzog, D.; Emmelmann, C. Design guidelines for laser additive manufacturing of lightweight structures in TiAl6V4. J. Laser Appl. 2015, 27, S14001. [CrossRef]

2. Liu, Y.; Wang, H.; Li, S.; Wang, S.; Wang, W.; Hou, W.; Hao, Y.; Yang, R.; Zhang, L. Compressive and fatigue behavior of beta-type titanium porous structures fabricated by electron beam melting. Acta Mater. 2017, 126, 58-66. [CrossRef]

3. Gibson, I.; Rosen, D.W.; Stucker, B. Additive Manufacturing Technologies; Springer: Berlin, Germany, 2010; Volume 238.

4. Guo, P.; Zou, B.; Huang, C.; Gao, H. Study on microstructure, mechanical properties and machinability of efficiently additive manufactured AISI 316L stainless steel by high-power direct laser deposition. J. Mater. Process. Technol. 2017, 240, 12-22. [CrossRef]

5. Rännar, L.-E.; Glad, A.; Gustafson, C.-G. Efficient cooling with tool inserts manufactured by electron beam melting. Rapid Prototyp. J. 2007, 13, 128-135. [CrossRef]

6. Li, R.; Liu, J.; Shi, Y.; Du, M.; Xie, Z. 316L stainless steel with gradient porosity fabricated by selective laser melting. J. Mater. Eng. Perform. 2010, 19, 666-671. [CrossRef]

7. Riemer, A.; Leuders, S.; Thöne, M.; Richard, H.; Tröster, T.; Niendorf, T. On the fatigue crack growth behavior in 316L stainless steel manufactured by selective laser melting. Eng. Fract. Mech. 2014, 120, 15-25. [CrossRef]

8. Spierings, A.B.; Levy, G. Comparison of density of stainless steel 316L parts produced with selective laser melting using different powder grades. In Proceedings of the Annual International Solid Freeform Fabrication Symposium, Austin, TX, USA, 3-5 August 2009; pp. 342-353.

9. Stamp, R.; Fox, P.; O'neill, W.; Jones, E.; Sutcliffe, C. The development of a scanning strategy for the manufacture of porous biomaterials by selective laser melting. J. Mater. Sci. Mater. Med. 2009, 20, 1839. [CrossRef] [PubMed]

10. Yasa, E.; Kruth, J.-P. Microstructural investigation of selective laser melting 316L stainless steel parts exposed to laser re-melting. Procedia Eng. 2011, 19, 389-395. [CrossRef]

11. Yasa, E.; Kruth, J.-P.; Deckers, J. Manufacturing by combining selective laser melting and selective laser erosion/laser re-melting. CIRP Ann.-Manuf. Technol. 2011, 60, 263-266. [CrossRef]

12. Strano, G.; Hao, L.; Everson, R.M.; Evans, K.E. Surface roughness analysis, modelling and prediction in selective laser melting. J. Mater. Process. Technol. 2013, 213, 589-597. [CrossRef]

13. Alsalla, H.H.; Smith, C.; Hao, L. Effect of build orientation on the surface quality, microstructure and mechanical properties of selective laser melting 316L stainless steel. Rapid Prototyp. J. 2017, 24, 9-17. [CrossRef]

14. Izzati, W.B.W.N.; Amirah, M.A.N.; Suleiman, D.Y.; Farazila, Y.; Aqilah, D.N. Effects of process parameters on the surface roughness of stainless steel 316L parts produced by selective laser melting. J. Test. Eval. 2018, 46. [CrossRef]

15. Spierings, A.B.; Herres, N.; Levy, G. Influence of the particle size distribution on surface quality and mechanical properties in am steel parts. Rapid Prototyp. J. 2011, 17, 195-202. [CrossRef]

16. Kochan, D.; Kai, C.C.; Zhaohui, D. Rapid prototyping issues in the 21st century. Comput. Ind. 1999, 39, 3-10. [CrossRef]

17. Yakout, M.; Cadamuro, A.; Elbestawi, M.; Veldhuis, S.C. The selection of process parameters in additive manufacturing for aerospace alloys. Int. J. Adv. Manuf. Technol. 2017, 92, 2081-2098. [CrossRef] 
18. Ahmadi, A.; Mirzaeifar, R.; Moghaddam, N.S.; Turabi, A.S.; Karaca, H.E.; Elahinia, M. Effect of manufacturing parameters on mechanical properties of $316 \mathrm{~L}$ stainless steel parts fabricated by selective laser melting: A computational framework. Mater. Des. 2016, 112, 328-338. [CrossRef]

19. Casati, R.; Lemke, J.; Vedani, M. Microstructure and fracture behavior of 316L austenitic stainless steel produced by selective laser melting. J. Mater. Sci. Technol. 2016, 32, 738-744. [CrossRef]

20. Yakout, M.; Elbestawi, M.; Veldhuis, S.C. On the characterization of stainless steel 316L parts produced by selective laser melting. Int. J. Adv. Manuf. Technol. 2017, 1-22. [CrossRef]

21. Spierings, A.B.; Starr, T.L.; Wegener, K. Fatigue performance of additive manufactured metallic parts. Rapid Prototyp. J. 2013, 19, 88-94. [CrossRef]

22. Yadroitsev, I.; Yadroitsava, I. Evaluation of residual stress in stainless steel 316L and Ti6Al4V samples produced by selective laser melting. Virt. Phys. Prototyp. 2015, 10, 67-76. [CrossRef]

23. Barari, A.; Kishawy, H.; Kaji, F.; Elbestawi, M. On the surface quality of additive manufactured parts. Int. J. Adv. Manuf. Technol. 2017, 89, 1969-1974. [CrossRef]

24. Ullah, A.; Caggiano, A.; Kubo, A.; Chowdhury, M. Elucidating grinding mechanism by theoretical and experimental investigations. Materials 2018, 11, 274. [CrossRef] [PubMed]

25. Sharif Ullah, A.; Fuji, A.; Kubo, A.; Tamaki, J.I.; Kimura, M. On the surface metrology of bimetallic components. Mach. Sci. Technol. 2015, 19, 339-359. [CrossRef]

26. Zerti, O.; Yallese, M.A.; Khettabi, R.; Chaoui, K.; Mabrouki, T. Design optimization for minimum technological parameters when dry turning of $\mathrm{AISI}_{3}$ steel using taguchi method. Int. J. Adv. Manuf. Technol. 2017, 89, 1915-1934. [CrossRef]

27. Anilli, M.; Demir, A.G.; Previtali, B. Additive manufacturing of laser cutting nozzles by SLM: Processing, finishing and functional characterization. Rapid Prototyp. J. 2018, 24, 562-583. [CrossRef]

28. Khorasani, A.M.; Gibson, I.; Goldberg, M.; Littlefair, G. A comprehensive study on surface quality in 5-axis milling of SLM Ti-6Al-4V spherical components. Int. J. Adv. Manuf. Technol. 2018, 94, 3765-3784. [CrossRef]

29. Sing, S.L.; An, J.; Yeong, W.Y.; Wiria, F.E. Laser and electron-beam powder-bed additive manufacturing of metallic implants: A review on processes, materials and designs. J. Orthop. Res. 2016, 34, 369-385. [CrossRef] [PubMed]

30. Zhong, Y.; Liu, L.; Wikman, S.; Cui, D.; Shen, Z. Intragranular cellular segregation network structure strengthening 316L stainless steel prepared by selective laser melting. J. Nucl. Mater. 2016, 470, 170-178. [CrossRef]

31. Saeidi, K.; Gao, X.; Zhong, Y.; Shen, Z.J. Hardened austenite steel with columnar sub-grain structure formed by laser melting. Mater. Sci. Eng. A 2015, 625, 221-229. [CrossRef]

32. Prashanth, K.; Eckert, J. Formation of metastable cellular microstructures in selective laser melted alloys. J. Alloys Compd. 2017, 707, 27-34. [CrossRef]

33. Mertens, A.; Reginster, S.; Paydas, H.; Contrepois, Q.; Dormal, T.; Lemaire, O.; Lecomte-Beckers, J. Mechanical properties of alloy Ti-6Al-4V and of stainless steel 316L processed by selective laser melting: Influence of out-of-equilibrium microstructures. Powder Metall. 2014, 57, 184-189. [CrossRef]

34. Frazier, W.E. Metal additive manufacturing: A review. J. Mater. Eng. Perform. 2014, 23, 1917-1928. [CrossRef]

35. Chowdhury, M.; Sharif Ullah, A.; Anwar, S. Drilling high precision holes in Ti6Al4V using rotary ultrasonic machining and uncertainties underlying cutting force, tool wear, and production inaccuracies. Materials 2017, 10, 1069. [CrossRef] [PubMed]

36. Ullah, A.S.; Harib, K.H. A human-assisted knowledge extraction method for machining operations. Adv. Eng. Inform. 2006, 20, 335-350. [CrossRef]

37. Shaw, M.C. Metal Cutting Principles; Oxford University Press: New York, NY, USA, 2005; Volume 2.

38. Liu, Y.; Liu, Z.; Jiang, Y.; Wang, G.; Yang, Y.; Zhang, L. Gradient in microstructure and mechanical property of selective laser melted AlSi10Mg. J. Alloys Compd. 2018, 735, 1414-1421. [CrossRef]

39. Chlebus, E.; Gruber, K.; Kuźnicka, B.; Kurzac, J.; Kurzynowski, T. Effect of heat treatment on the microstructure and mechanical properties of Inconel 718 processed by selective laser melting. Mater. Sci. Eng. A 2015, 639, 647-655. [CrossRef] 
40. Jawahir, I.; Brinksmeier, E.; M'saoubi, R.; Aspinwall, D.; Outeiro, J.; Meyer, D.; Umbrello, D.; Jayal, A. Surface integrity in material removal processes: Recent advances. CIRP Ann.-Manuf. Technol. 2011, 60, 603-626. [CrossRef]

41. Meyers, M.A.; Chawla, K.K. Mechanical Behavior of Materials; Cambridge University Press: Cambridge, UK, 2009; Volume 2.

42. Attar, H.; Prashanth, K.; Chaubey, A.; Calin, M.; Zhang, L.C.; Scudino, S.; Eckert, J. Comparison of wear properties of commercially pure titanium prepared by selective laser melting and casting processes. Mater. Lett. 2015, 142, 38-41. [CrossRef]

(C) 2018 by the authors. Licensee MDPI, Basel, Switzerland. This article is an open access article distributed under the terms and conditions of the Creative Commons Attribution (CC BY) license (http:// creativecommons.org/licenses/by/4.0/). 